\title{
A New Quest is Available: Seeing, Walking, and Narrating The City
}

\author{
Elita Nuraeny ${ }^{1}$ \\ ${ }^{1}$ Department of Architecture/Faculty of Engineering, Universitas Indonesia, Indonesia \\ elitanuraeny@ui.ac.id
}

\begin{abstract}
Walking becomes a conversation of past, present, and future, between our body and the city. However, today's modern hand-held map demands us to look down, disrupting the dialogue between the body and city. Like a modern role-playing game, the map guides us to our quest mark beyond minimum consideration of the present time. The map makes the quest mark and path visible; yet, our reality's in-between space is overlooked. Following the idea of a hidden quest mark in our real world, this study explores the lost narrative between our body and the city. The study examined a project named Location + that follows spatial history, experiences, and the journey beyond a hidden church of the Knights Templar in London. The project is filled with instructions to decipher codes, directing people to the church. Using psychogeography, the project Location + approaches a spatial narrative using site writing and creative map-making specific to the site by emphasizing the idea that our journey matters. This project allows a dialogue between the body and the city.
\end{abstract}

(C) 2018 IJBESR. All rights reserved.

Keywords: site specificity, psychogeography, navigating, site writing, London.

\section{Introduction}

People have lost interest in the real world. Technology has brought humanity to a state where they no longer pay attention to reality but instead take comfort behind smartphones and social media. John Bingham-Hall criticized - as well as intrigued by - the phenomenon, saying that people turn themselves into voyeurs of everyday life [1]. The city becomes a series of interior bubbles or a customized experience with smartphones, showing only personal preferences. The act constricts other unrelated aspects of the city and labels it as the unrecommended experience.

An example of a customized interior can be seen in mobile maps, especially during searching and navigating the city. Navigating applications, such as Google Maps and Citymappers, begin as the user submits the location (beginning and ending). The system will work independently to find the best routes based on the current location and time. Soon, options and alternatives emerge, consisting of several routes, estimated time assumption, available transportation modes, and - when the option for public transport is chosen - the amount of money to spend for a single trip. With technology, exploring the city is suited to people's preferences - travel slowly with buses, faster with trains, or spend more money on taxis' convenience.

However, relying solely on a map has a low impact on the overall spatial experience because it fails to represent and limit the real world. The map shows the representation of what and how people will like to explore and negate other unrelated factors, placing them in our preferred interiors' background. Therefore, Mobile maps create a personalized portion of the city that binds people even more to their smartphones, taking them away from the real 
world. A critic by Brian Dixon reflected how people engross with their smartphones and always looking down [2], paying less attention to their surroundings.

The map is a calculated interface to help people pinpoint or recognize signs while exploring the city [3]. Only partial information and representations are reflected in maps, creating a feeling of detachment and alienation even in our cities. In a series of codes, the map becomes a guide through the physical world, not a complete copy of the world itself. Detachment and alienation come from the map's inability to follow the dynamic space.

The map is stasis and works with twodimensional figures in a frozen image. Space, however, has the time factor. Doreen Massey expressed that time and space (which further will be referred to as space/time) cannot be separated [4]. To further extend Massey's notion in the context of navigation and urban exploration, Eric Sheppard added that space/time is the unpredictable outcome of social and physical processes, creating places and positionality [5]. In other words, space/time must be looked at as a unity in navigating and portraying the city. Another fascinating insight came from Manuel Castell, saying that the meaning of space/time will continue to expand as the city grows and society evolves [6]. Maps, on the other hand, cannot recreate such dynamic transformation every second. According to Antoine Picon, maps expand the gap between physical and digital reality, because it is designed to be a general reference applicable to all [7]. Another problematic factor was pointed out by Vittoria DiPalma, based on how the aerial view often represents maps. In her research, DiPalma said that the aerial view does not conform to the principal perspective based on people's viewpoint [8], which is then misleading and confusing to follow.

Therefore, to make sense of the city, people must locate themselves in the city. Picon [7] stated that "in the digital world, we do not use only software and scripts, but also recipes and even spells," referring to the visual information in the digital world as a guide to explore the city. The map is a series of suggestions, not a rigid path people must follow. The generalized icons are based on shared knowledge, whereas observation is crucial to experience moving situations and engage emotionally [9]. The key is to look around, and people will regain their positions in the city, no longer alien.

The Situationist expressed the idea of exploring the city by combining route planning with a map and looking around through psychogeography. An interesting quote by John R. Stilgoe [10] said that "history is on the wall, but only those willing to look up from newspaper or laptop computer glimpse it and ponder," reflecting on the Situationist's approach to exploring the city. Using psychogeography, the Situationist captures the city as a set of situations beyond the visible and tangible factors [11]. Situations refer to the impact of the tangible environment on human emotions. The Situationist, however, understood the importance of maps in urban exploration as an overview of the real world. According to Guy Debord [12], the map is a media, one of the influential figures of psychogeography and the Situationist. There are some expected situations while reading a map, but it will be captured only through observation [12]. Situations or encounters are present stories, occurring currently in front of our eyes, whereas beyond maps, a world filled with stories and places waiting to be discovered exist [10]. Stories in Stilgoe's notion are fragmented and scattered around in a series of interiors, crossing and connecting each other in a series of narratives.

Walking is a spatial acting-out of place [7][13] that connects the present space with the past. According to Michel de Certeau, walking is crucial in making up a city because stories start at ground level; hence, his critique on every 
metropolis' aerial view with tall buildings and skyscrapers [13]. De Certeau also emphasized that stories of the city are told and created through footsteps [13]. Walter Benjamin expressed a similar idea [14], where walking is a critical instrument of exploring the city for whoever walked the road will "learn the power it commands." Power here refers to the human capability of identifying and positioning themselves in the city. Through walking, people align their minds, bodies, and the world around them [15].

Walking is a speechcraft that allows people to explore further without architectural boundaries limiting their understanding of space [7][13]. Time exists in both language and walking that tells people about the past, present, and future of a city. The past is behind us as the trail we left and the icons representing the old generalized knowledge in a map. The past also represents stories of those before us, giving a distinctive personality to the city. The past, including history, makes the city as it is today, whereas the present relates to past and current situations around us. The future lies within the map through the icons. People might anticipate situations in the future, but they will miss the future without embracing the present.

The map is a product of past knowledge. Relying on a map will set us behind, unable to experience the present, and the narrative will be lost and trapped in people's interior. Walking serves as an in-between space connecting the past and present. By observing, people can reclaim their position in the city and nurture their sense of belonging after falling through the alienation provoked by the map. Although it mediates information from the city to us, the map is a monologue but delays our responses.

Walking, on the other hand, allows people to have a dialogue with the city. It is a two-way narrative of people's interior and the city's past, working simultaneously to share information from both the past and present. The map provides the experience of others and the past. As people look up, they pull their bodies and minds from history and gaze into the present.

This paper revisits a project in 2017 called Location + of Temple Church in London, United Kingdom. The project adopted the Situationist's method to explore the city through deriving [16] and was inspired by Brian Dixon's notion to look up [2]. Location + combined a map with creative writing to navigate London to Temple Church, slightly hidden by buildings' layers. Research of utilizing maps and observation had been done extensively by the Situationist [11][12][16], while Valérie November, Eduardo CamachoHübner, and Bruno Latour studied navigation in the risky territory [3]. Walking as a method of urban exploration is also suggested as a complete exploration [13][14][15]. This paper adds to the discourse of navigating with a map while subtly encouraging the user to observe their surroundings in an unorthodox, creative output.

\section{Material and Methods}

The project was conducted by using qualitative methodology, both literature study, and field observation. In the literature study, the theory on psychogeography and the Situationist's approach of exploring the city is the primary source to conduct a successful observation later in the second phase. More specifically, the Location + adopted Guy Debord's theory of deriving, a technique to explore through various ambiances capturing social and physical environment as a set of situations [16]. The first step is to let go and drop any relations to be immersed with the situation. Other than psychogeography theories and their related knowledge, additional materials regarding each encountered place were recorded and researched through archives or secondary readings. The Survey of London collects various archives about London through history and provides useful information. Publications 
regarding the history of Temple Church itself were studied thoroughly to create one cohesive narrative.

The next phase of this research was field observation. Despite their criticism of conventional maps on understanding the social construct in the built environment, the Situationist required a map before venturing into the city. A traditional map is crucial for psychogeography to plan a walking route and possible encounters [16]. Therefore, in working on Location +, the first step was to look into the current map. The project used Google Maps as its initial guide through London. Planning the route was the second task before observation. However, unlike the Situationist, Location + did not have its starting point. Instead, the project had a destination. Therefore, I replicated the Situationist's approach to planning the route as if the church was the starting point. When the destination was determined, I walked, tracing back to the church instead.

The last step was to record the observation. Various ways of documentations were tested, but two were most successful in capturing all situations, which are voice recording and photographing. The recording was the fastest way to input data in a less intrusive way towards other people. Voice recording also enabled me to take notes without missing any situations simultaneously. Photos were the second method to collect undescribed encounters or details. The result was a new set of maps that were less dictating and open-ended for a more immersive experience in London.

\section{Results and Discussions}

The Location + project was conducted in early 2017 in London, the United Kingdom, as part of the Theorising Practice course at the Bartlett School of Architecture. The Location + is a set of creative maps, highlighting the journey rather than the architectural form through writings and a set of instructions. The project aimed to create a new and intimate connection for the map holder to the City of London, even more, to uncover new facts and places forgotten in daily lives.

The location + project destination was Temple Church in London, which was constructed by the Knights Templar in 1185. The idea of designing a set of maps was inspired by how the Temple Church is hidden. It was said that the seclusion of Temple Church is intentional as a defense mechanism by the Templar Knights against their enemy and to protect supposedly treasure hidden under the church [17]. The Location + project offered a different approach to navigation by providing a set of written directions leading towards Temple Church instead of icons adorned by standard maps. To write about a site is to draw the relationship between objects, people, and space [18]. Through words, the project connected stories from the past - history, myths, and legends related to the church — and the present. The written direction was designed to uncover situations in London, both in the past and present, eventually leading people to Temple Church. The project encouraged people to decipher codes to Temple Church and narrated the past paths that people walked daily. The text showed people the predetermined path to the church by Google Maps but also offered new ones to be explored. However, before designing and making the map, successful psychogeography requires at least a route. To decide which route, where and how long it should take, the church served as the key inspiration source. As seen in Figure 1, I paid closer attention to the church's 14 pillars, of which six columns are found in the Round (the circular shape), and eight others support the Chancel (the rectangular shape). Each column is then converted into $1 \mathrm{~cm}$. Using a $14 \mathrm{~cm}$ thread, I scaled Google Maps in 1:100 where 1 $\mathrm{cm}$ represented $100 \mathrm{~m}$; therefore, I have at least $1.4 \mathrm{~km}$ facing away from Temple Church. 

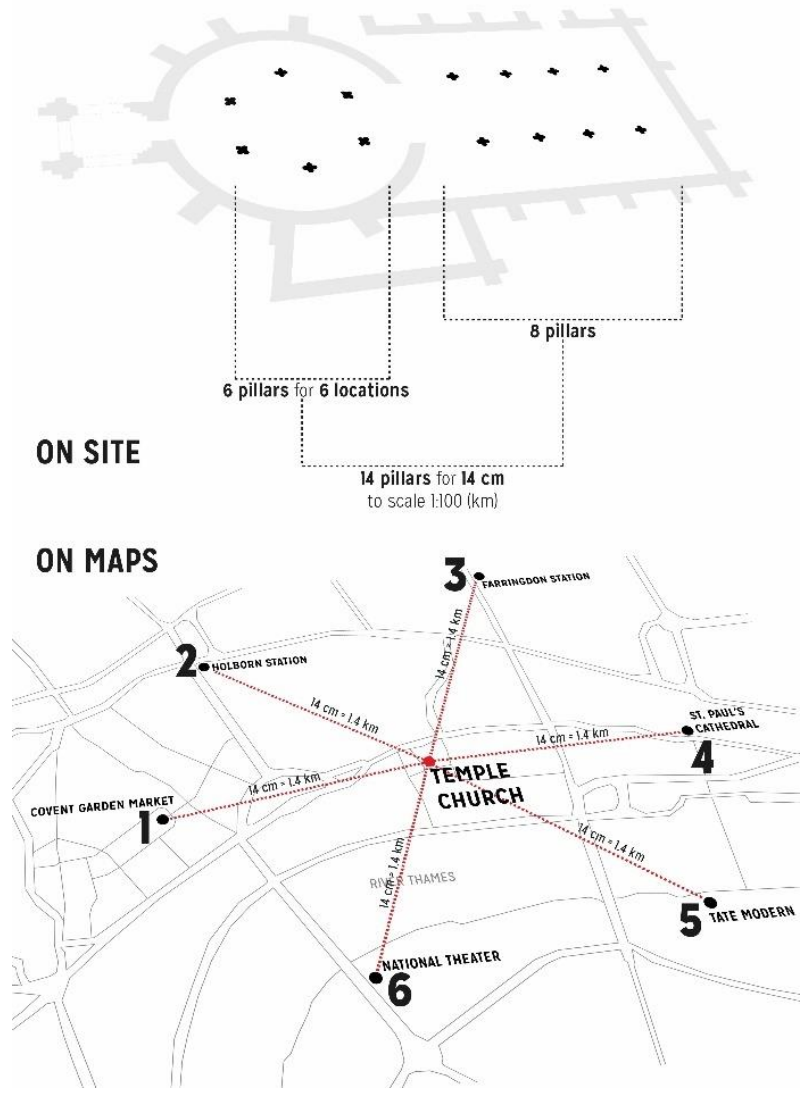

Source: (Author, 2018)

Figure 1. Each column found in Temple Church represents $1 \mathrm{~cm}$ of thread equal to $100 \mathrm{~m}$. By considering the 14 pillars, the distance between the church and drop point is at $\sim 1.4 \mathrm{~km}$.

The number of maps and center points was determined based on the church's plan, especially the Round - a prominent place within the church - tying the Knights Templar's lore in London to the city itself. Under the Round of Temple Church, supposedly lies the Knights' treasures from years of serving kings and noble in England [17][19], and artifacts brought back from the Crusade. Since its consecration in 1185, the Round's shape is preserved until today, even after the Great Fire of London and Nazi air raids bombarded the area surrounding the church in World War II [17][19]. Seeing the significant impact of the Round, I decided to start from the Round and walked outside the church. Overall, six combinations on the Round's ceiling serve as the starting point to determine each location expanding from the church. After scaling and measuring, the six locations are Holborn Station, Farringdon Station, St. Paul's Cathedral, Covent Garden Market, National Theatre, and Tate Modern. Embracing the mysterious legend of Temple Church and the Knights Templar, the completed maps of location + was hidden at each location. The map addressed those who found the map as the chosen one, finding the key to unlock a mystery kept in central London (see Figure 1).

The next step before writing and designing the map was exploring the city by walking. Although slower than cars, The Situationist perceived walking as a suitable method to understand their cities because it allows people to connect with the world around them [15]. Describing and recording the present were manageable by walking and having a series of recorded monologues.

However, collecting the past is obtainable from digging into archives, old texts, and various pop culture references available. The Survey of London provided readings and images about London's built environment throughout history [20]. Based on the observation of the present and awareness of history, the spatial narrative of Temple Church and other locations can be separated into three main narratives, namely:

1. the Knights' existence in London,

2. the story of surviving the Great Fire of London in 1666, and

3. the terror of air raids in 1941.

The location + project highlighted the journey rather than the architectural form. The idea of exploration was emphasized by the maps being presented in a folding paper technique, with each gesture of unwrapping the paper symbolizing uncovering the lore, history, and further spatial information regarding Temple Church. With location +, the surroundings became crucial and must be observed because the next clue is among them. Telling stories of 
the past also leads people to places where the Knights once walked.

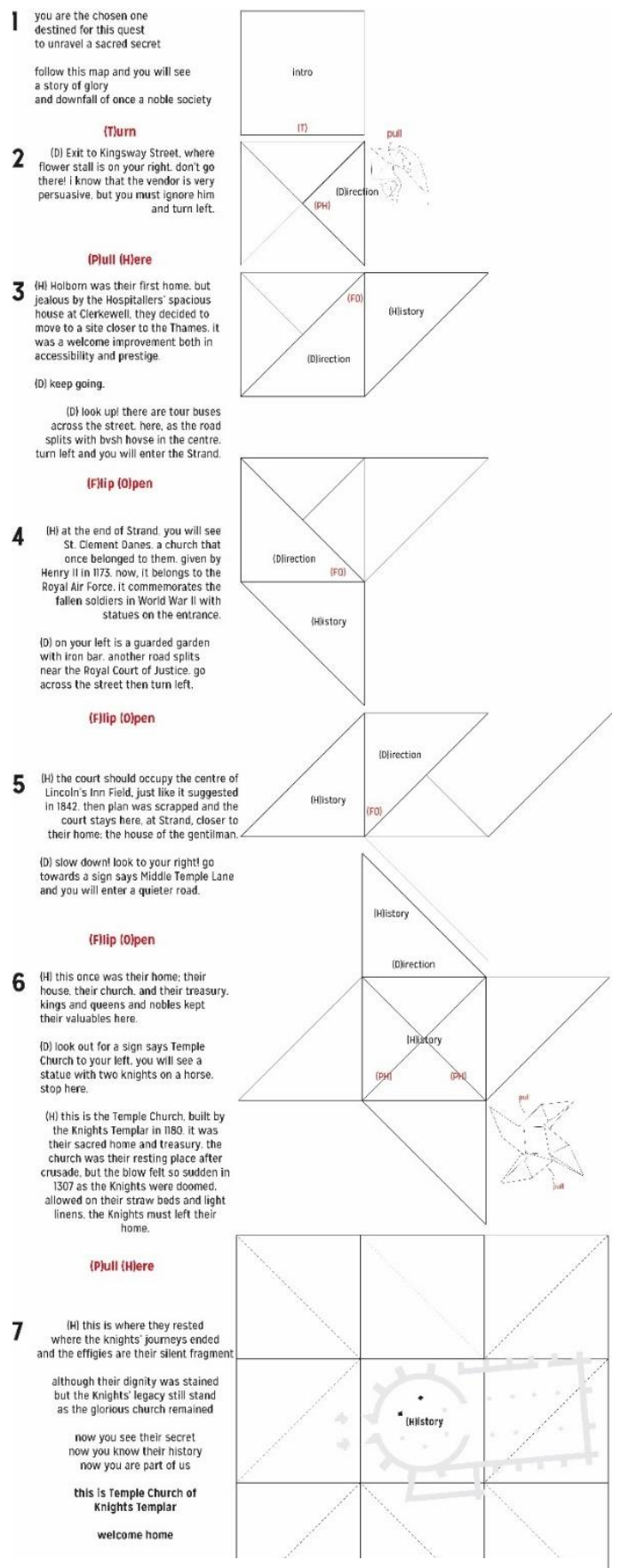

Figure 2. An illustration of the Temple Church's ceiling plan and how the shape inspired the overall look of the map. Source: (Author, 2018)
As the center and destination of this map, another inspiration came from the Temple Church's ceiling pattern, especially at the Round. From its columns pattern, the Round creates a hexagonal shape. The ceiling pattern, then, consisted of six rectangular shapes with four triangular shapes. The combination of rectangles and triangles became the model for the final product. Figure 2 shows the creative process from the product (up, first picture) to the Round ceiling (below, last picture).

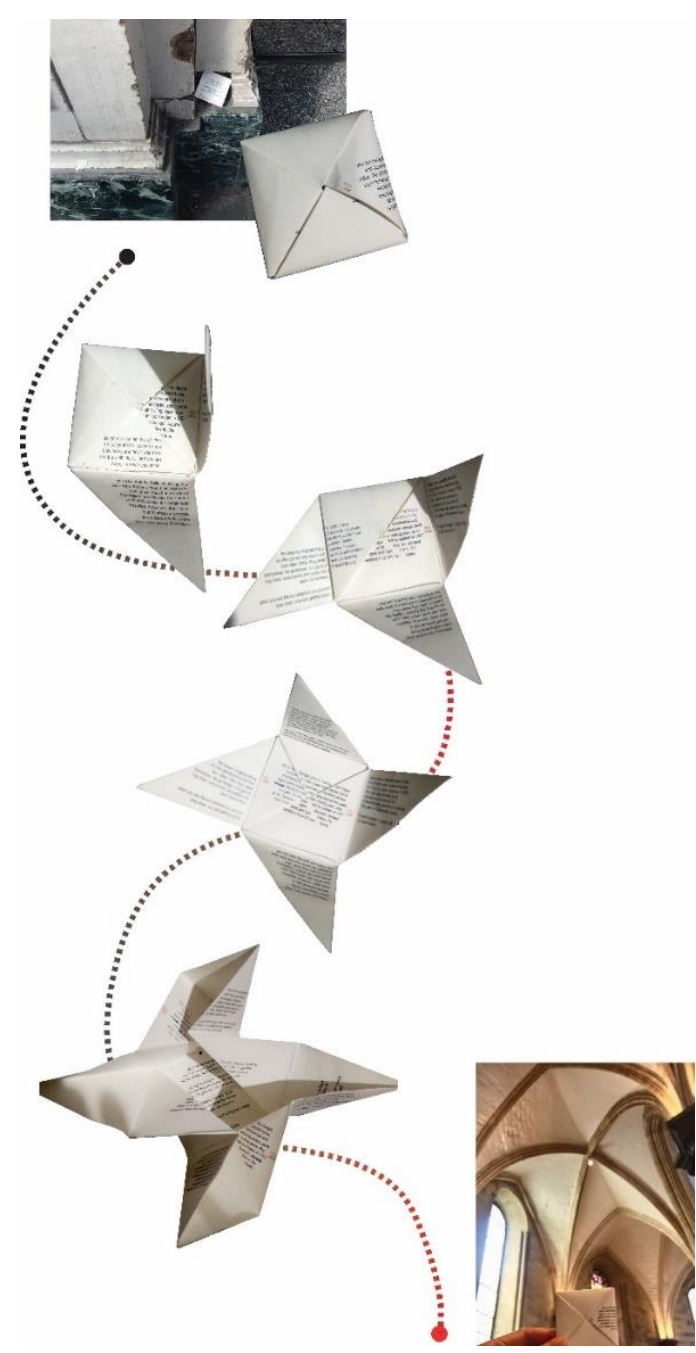

Source: (Author, 2018).

Figure 3. A step-by-step guide to unwrap the map by following the written instruction. Stories about the Temple Church are also included until the map reaches its destination.

Figure 3 shows the journey from Holborn Station's map. Based on the location, Holborn 
falls into the first narrative emphasizing the myth and legend of the Knights Templar because Holborn was the Knights' first headquarters in London [17]. The Hospitallers' rivals lived in Clerkenwell, not too far from where Farringdon Station is today. The following narrative continued the Knights myth, who served the nobles and kings of England as bankers and their church as the monarch's vault [18]. As we draw closer to the church, the story changed to the Knights Templar's downfall and how they lost their home.

In Figure 3, we can see how the story slowly revealed and experienced. Through a series of history (indicated with $(\mathrm{H})$ in Figure 3 ) and direction (indicated with (D) in Figure 3), the observer traveled across central London to find the Temple Church. The alignment on the left or right indicated a landmark where the finder's stand. For example, the command to "keep going" (the third step, the second paragraph in Figure 3) was on left alignment because the left sidewalk must be taken. The alignment then changed to the right once a scenery or another landmark popped up, such as tour buses (the third step, the third paragraph in Figure 3). Each important location or interesting sights were indicated through left and right, directing people to their destination but less intruding and demanding.

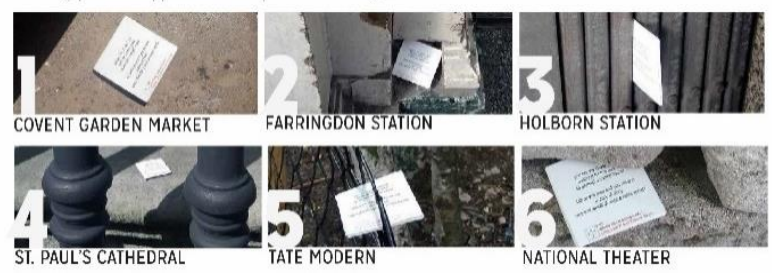

Figure 4. The final location for each map. Source: (Author, 2018).

The final result was $6 \mathrm{~cm} \times 6 \mathrm{~cm}$ maps (expands to $18 \mathrm{~cm} \times 18 \mathrm{~cm}$ ) scattered around London at (1) Covent Garden Market (on the doorstep of
St. Paul's Church), (2) Farringdon Station, (3) Holborn Station, (4) St. Paul's Cathedral (under the Queen Victoria statue), (5) Tate Modern, and (6) National Theater (see Figure 4). The product had a relatively small size that fits in an adult's palm. The small, compact, and discreet size reflected the idea of creating a less intrusive map. As illustrated in Figure 3, Location + maps were text-based. The length of each paragraph in the direction section was timed accordingly to suit the pace. Therefore, when a new instruction came up, the observer will be at the correct spot.

\section{Conclusion}

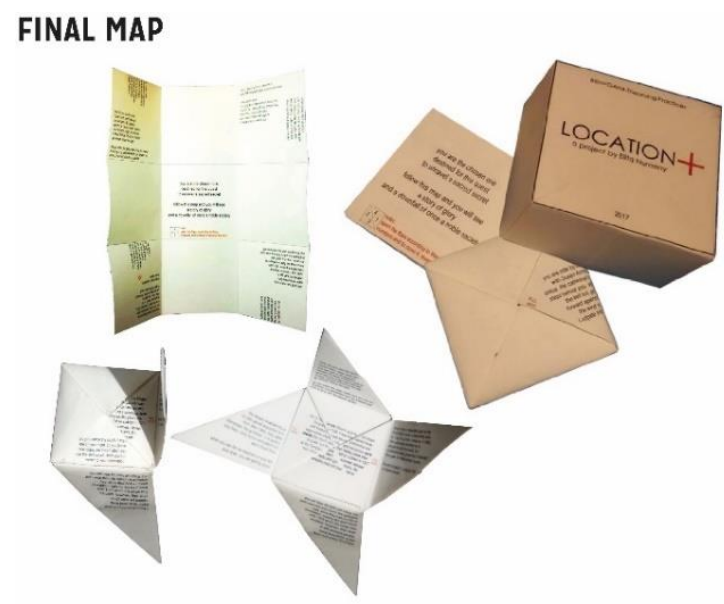

\section{CONVENTIONAL MAP}

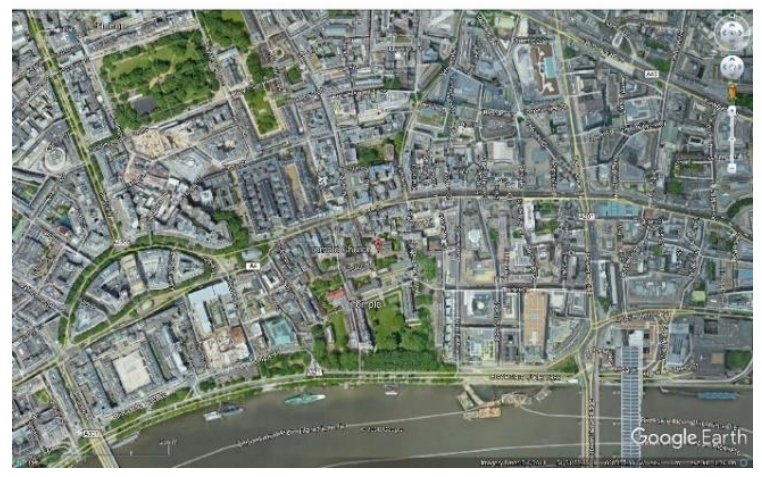

Source: (Author, 2018 (above) and Google, 2020, imagery date: $5 / 6 / 2018$, (below, last accessed on $10^{\text {th }}$ December 2020)).

Figure 5. A comparison between the final map of Location + and conventional map 
We live in a series of interiors, a customized experience showing us what we prefer and desire. Our dependency on mobile maps has encouraged these interiors to remain solitaire, unconnected. Detachment and alienation arise because of the map's incapability of showing the time-space dynamic relationship. The map offers a monologue, narrating a single story at the time, while in-time responses are lost in translation. We can regain our position in the city by looking up and observing the city. In that way, the city answers our response to the map is immediately, and we respond again, creating an active dialogue between our bodies and the city. Then, walking becomes the act of speaking, narrating the present (the current set of situations found around us) and the past (previous stories and places we passed) and connecting the city's interiors.

Location + emphasizes the experience of navigating the city through a combined effort of reading a map and observing the surroundings. Taking Temple Church as the research study and psychogeography as the primary methodology, Location + practices walking as a conversational tool with the city. The project also considers walking as a bridge between the past and present, making sense of the inbetween space we once lost while using the map as our navigation instrument. Unlike the conventional map - whether digital or paperbased - Location + eliminates unnecessary and distracting signs but maintaining engagement with the city from a personal level (see Figure 5 ). When the body has a deep, meaningful, and thoughtful conversation with the city, we are no longer lost between interiors. Figure 5 shows another prominent and significant contrast between the proposed and available map. The conventional map (represented by Google Earth map) has its aerial view, distancing its viewers from the situation from the eye level. On the other hand, Location + maps operate and direct from the eye-level, anchoring its users in the city.
Driven by the idea of looking up to the city and slowly absorbing a set of situations encountered, Location +'s map-making method proposed by Location + is suitable to increase awareness of the built environment and past stories in the city. Location + also shows a new way and potential to create an engaging map less obtrusive for people in new cities. Therefore, whenever a new quest emerges, we are ready to walk the path and talk to the city, as it narrates different stories from the past and present. However, Location + requires a secondary perspective, while the current project was mainly based on personal experience. By adding other viewpoints, the project can expand its level of engagement with more people.

\section{Acknowledgement}

Many thanks to Jane Rendell from Bartlett, London, for your guidance during the development of this project and the thoughtprovoking conversations we had in class. The 'Theorising Practice' program will always inspire my works in the future.

\section{References}

[1] John B-H. On the search for space in the digital city: A dispatch from granary square. In: Ben C, Rebecca R, editors. Urban Pamphleteer \#1: Future and Smart Cities, London: UCL Urban Laboratory, 2013, p. 6-8.

[2] Brian D. A mobilisation of walking: GPS technology and the exploratory urban walker. In: Ben C, Rebecca R, editors. Urban Pamphleteer \#1: Future and Smart Cities, London: UCL Urban Laboratory, 2013, p. 17-19.

[3] Valerie N, Eduardo CH, and Bruno L. Entering a risky territory: space in the age of digital navigation. Environment and Planning D: Society and Space 2010:28: 581-599.

[4] Doreen M. Space-Time, 'Science' and the relationship between Physical Geography and Human Geography. Transactions of the Institute of British Geographers. 1999: 24: 261-276.

[5] Eric S. The spaces and times of globalization: place, scale, networks, and positionality. Economic Geography 2002: 78: 307-330.

[6] Manuel C. "An introduction to the information age" In Gary B and Sophie W., editors. The Blackwell City Dweller, Chichester: Wiley-Blackwell, 2010, p. 40-48. 
[7] Antoine P. Digital Culture in Architecture: An Introduction for the Design Professions. Basel: Birkhäuser GmbH, 2010.

[8] Vittoria dP. "Zoom: Google Earth and global intimacy" in Vittoria dP, Diana P and Marina L., editors. Intimate Metropolis, New York: Routledge, 2009, p. 239-270.

[9] Suzie A. "Urban and interior: techniques for an urban interiorist" in Suzie A. et al., editors. Urban Interior: Informal Explorations, Interventions and Occupations, Germany: Spurbuchverlag, 2011.

[10] John RS. Outside Lies Magic: Regaining History and Awareness in Everyday Places. New York: Walker Publishing Company Inc., 1998.

[11] Steve P. Real Cities: Modernity, Space, and the Phantasmagorias of City Life. London: SAGE Publications Ltd., 2005.

[12] Guy D. Society of the Spectacle. New York: Zone Books, 1994.

[13] Michel dC. The Practice of Everyday Life. London: University of California Press, Ltd., 1984.
[14] Walter B. One-Way Streets and Other Writings. London: Verso, 1992.

[15] Rebecca S. Wanderlust: The History of Walking. United Kingdom: Penguin Books Ltd., 2001. Kindle. [16] Guy D. "Theory of the derive" in Ken K., editor and translator. Situationist International Anthology: Revised and Extended Edition. Last modified 13 December 2011. http://www.bopsecrets.org/SI/2.derive.htm.

[17] David L. and Robert D. The Temple Church in London. London: Historical Publications. Ltd., 1997.

[18] Jane R. Art and Architecture: A Place Between. New York: I.B. Tauris Publishers, 2006.

[19] David P. and Robin GJ. The Temple Church in London: History, Architecture, Art. Suffolk: The Boydell Press, 2010.

[20] British History Online. Collection from Survey of London. Last modified 30 November 2020. https://www.british-history.ac.uk/search/series/surveylondona 
International Journal of Built Environment and Scientific Research p-issn: 2581-1347 | e-issn: 2580-2607 | Pg. 127 - 136

(This page is intentionally left blank) 